\title{
LEGALITAS PEMBUBARAN BADAN USAHA MILIK DAERAH BERBADAN HUKUM PERSEROAN TERBATAS (PT. DAERAH MAJU BERSAING)
}

\author{
Djumardin \\ Fakultas Hukum Universitas Mataram \\ Jl. Majapahit No.62 Mataram \\ Telp (0370) 633035, Fax 626954 \\ Email : drdjumardin@gmail.com
}

\begin{abstract}
ABSTRAK
Penelitian ini bertujuan untuk mengetahui eksistensi PT.DMB pasca penjualan saham oleh PT. MDB dan mekasime pembubaran Badan Usaha Milik Daerah yang berbadan hukum Perseroan Terbatas (PT.DMB). Metode penelitian yang digunakan dalam tulisan ini adalah penelitian normatif dengan metode pendekatan peraturan perundang-undangan (statute approach); pendekatan konseptual (conseptual approach); dan pendekatan Kasus (casse approach). Bahwa Penjualan saham oleh MDB tidak secara otomatis menyebabkan bubarnya PT.DMB. Pembubaran PT. DMB tetap mengacu pada UU Perseroan Terbatas (UU Nomor 10 Tahun 2007)
\end{abstract}

Kata Kunci : Penjualan Saham, Pembubaran PT.

\section{A. PENDAHULUAN}

Indonesia merupakan suatu negara yang kaya akan sumber daya alam dan mineral seperti minyak bumi, tembaga, timah dan emas serta bahan galian lainnya. Mengingat begitu banyaknya potensi hasil kekayaan alam yang dimiliki yang bisa dimanfaatkan, maka negara mempunyai peran yang begitu besar terkait dengan pengaturan atas penggunaan sumber daya alam tersebut sehingga dapat mensejahterakan rakyat. Hal ini dijelaskan dalam ketentuan Pasal 33 ayat (3) UndangUndang Dasar Negara Republik Indonesia tahun 1945 yang menyatakan bahwa bumi dan air dan seluruh kekayaan alam yang terkandung didalamnya dikuasai oleh negara dan dipergunakan sebesar-besarnya untuk kemakmuran rakyat.

Sebagai tindak lanjut dari ketentuan Pasal 33 ayat (3) Undang-Undang Dasar 1945 tersebut, maka lahir Undang-Undang Nomor 1 Tahun 1967 tentang Ketentuan Pokok Penanaman Modal Asing dan
Undang-Undang Nomor 11 Tahun 1967 yang Ketentuan Pokok Pertambangan Umum .

Dimana melalui instrumen hukum inilah diperkenalkan sistem kontrak karya sebagai alternatif pemanfaatan dan pengolahan sumber daya alam di Indonesia khususnya kekayaan mineral berupa tambang.

Kontrak Karya adalah perjanjian karya antara Pemerintah Republik Indonesia dengan Perusahaan Berbadan Hukum Indonesia yang bertujuan untuk melakukan eksplorasi, studi kelayakan, konstruksi, produksi dan penjualan atas hasil galian bahan mineral di Indonesia

Dalam Undang-Undang Nomor 25 Tahun 2007 tentang Penanaman Modal menyatakan bahwa persetujuan penanaman modal dan izin pelaksanaan yang telah diberikan oleh Pemerintah berdasarkan Undang-Undang Nomor 1 Tahun 1967 tentang Penanaman Modal Asing dinyatakan tetap berlaku sampai dengan berakhirnya persetujuan penanaman modal dan izin pelaksanaan tersebut. Sedangkan Undang-Undang Nomor 
4 Tahun 2009 tentang Pertambangan dan Batu Bara menyatakan bahwa kontrak karya dan perjanjian karya pengusahaan pertambangan batu bara yang telah ada sebelum berlakunya undang-undang ini tetap diberlakukan sampai jangka waktu berakhirnya kontrak atau perjanjian.

Salah satu bentuk penanaman modal asing di bidang pertambangan umum yang dituangkan dalam bentuk kontrak karya di Indonesia adalah PT. Newmont Nusa Tenggara (PT. NNT) yang terletak di wilayah Nusa Tenggara Barat.

Berdasarkan ketentuan dalam kontrak karya yang ditandatangani oleh Pemerintah Indonesia dengan PT. NNT adalah mengenai promosi kepentingan nasional (promotion of national interest) dimana kewajiban bagi perusahaan untuk melaksanakan divestasi saham kepada Pemerintah Indonesia sesuai dengan ketentuan Pasal 24 ayat (3) Kontrak Karya.

Dalam kontrak karya, saham PT. NNT harus menjual sahamnya hingga $51 \%$ ke pihak nasional setelah 10 tahun berproduksi. Mengingat PT. Pukuafu Indah mempunyai $20 \%$ saham pada PT. NNT sebagai syarat pembentukan perusahaan berbadan hukum Indonesia, maka sisa saham PT. NNT yang akan didivestasi ke pihak nasional sebesar $31 \%$. Karena saham 20\% dari PT. Pukuafu Indah dianggap sebagai bagian dari "pihak nasional". Penjualan itu akan dilangsungkan secara bertahap hingga tahun 2010 dengan perincian sebagai berikut: ${ }^{1}$

1) Pada tahun Kelima (2005) tidak ada kewajiban divestasi sebesar 15\%.

2) Pada tahun Keenam (2006) kewajiban divestasi sebesar adalah 23\%-20\% $=3 \%$.

3) Pada tahun Ketujuh (2007) kewajiban divestasisebesar $7 \%$ sehinggatotalnya $30 \%$.

4) Pada tahun Kedelapan (2008) kewajiban divestasisebesar 7\% sehinggatotalnya37\%.

5) Pada tahun Kesembilan (2009) kewajiban divestasisebesar $7 \%$ sehinggatotalnya $44 \%$.

Indonesia Corruption Watch www.antikorupsi.org Jakarta, 10 Juni 2016 yang diakses pada Tanggal 9 Agustus 2018
6) Pada tahun Kesepuluh (2010) kewajiban divestasisebesar $7 \%$ sehinggatotalnya $51 \%$.

Partisipasi modal nasional dalam perusahaan modal asing telah menjadi kecendrungan yang umum baik di negaranegara yang sedang berkembang maupun di negara-negara maju. itu merupakan pencerminan nasionalisme di bidang ekonomi dan keinginan untuk menghindarkan ketergantungan pada kontrol asing terhadap perekonomian mereka. Negara-negara penerima modal telah melakukan penekanan terhadap joint venture internasional agar supaya mayoritas penyertaan berada pada pihak nasional melalui berbagai sistem. ${ }^{2}$

Dalam pelaksanaan divestasi PT. NNT tahap tahun 2006 dan sampai tahap 2009 sebesar 24\%, pihak yang membeli saham tersebut adalah Pemerintah Daerah Nusa Tenggara melalui Konsorsium tiga Daerah yakni Provinsi Nusa Tenggara Barat, Kabupaten Sumbawa Barat dan Kabupaten Sumbawa dengan komposisi kepemilikan saham (Provinsi: 40\%, KSB: 40\%, Sumbawa: $20 \%$ ) dan dari Konsorsium tersebut terbentuk PT. Daerah Maju Bersaing (PT. DMB) yang selanjutnya akan dipergunakan sebagai badan hukum untuk melakukan pembelian saham divestasi PT. NNT sebanyak 24\% dari seluruh total saham PT. NNT. Akan tetapi dalam pelaksanaanya PT. DMB tidak dapat melaksanakan pembelian 24\% saham tersebut karena dana yang dibutuhakn cukup besar yaitu sebesar USD 865.000.000 atau Rp: 8,6 triliun rupiah. Menyadari hal itu maka PT. DMB bermitra melalui perjanjian kerja sama dengan Pihak Ketiga yaitu Perusahaan Swasta PT. Multi Capital, sehingga dari hasil kerja sama tersebut maka dibentuk PT. Multi Daerah Bersaing (PT. MBD). Adapun Komposisi kepemilikan saham dalam PT. Multi Daerah Bersaing adalah 25\% Saham di miliki oleh PT. DMB dan 75\% saham dimiliki oleh PT. Multi Capital.

${ }^{2}$ Erman Radjagukguk dalam tulisannya "Joint-Venture Policy Relationship Between Majority And Minority Shareholers". Tanpa tahun 
Akan tetapi seiring dengan perkembangan orientasi ekonomi telah dicapai kesepakatan bahwa 25\% saham milik PT. DMB telah dijual dan dialihkan ke PT. Multi Capital dengan nilai investasi sebesar Rp. 500.000.000.000 (lima ratus miliar rupiah)

Berdasarkan uraian latar belakang diatas, maka ada beberapa rumusan masalah yang diangkat dalam penelitian ini yaitu:

1. Apakah dengan terjualnya saham PT. DMB pada PT. MDB mengakibatkan PT. DMB bubar?

2. Bagaimanakah mekanisme pembubaran Badan Usaha Milik Daerah yang berbadan hukum Perseroan Terbatas (PT. DMB)?

\section{B. PEMBAHASAN}

\section{Eksistensi PT. DMB pasca penjualan sa- ham PT. MDB.}

Berdasarkan ketentuan Pasal 12 Peraturan Daerah Pemerintah Provinsi NTB Nomor 4 tahun 2010 tentang Perseroan Terbatas (PT) Daerah Maju Bersaing bahwa kekayaan Perseroan terdiri dari nilai seluruh kekayaan perseroan termasuk 25\% (dua puluh lima perseratus) saham Perseroan pada PT. MDB. Dengan demikian startus 25\% saham PT. DMB pada PT. MDB merupakan salah satu unsur modal atau kekayaan Perseroan selain penyertaan modal dari masing-masing daerah yaitu Provinsi Nusa Tenggara Barat sebesar $40 \%$, Kabupaten Sumbawa Barat 40\% dan Kabupaten Sumbawa 20\%.

Oleh karena kepemilikan saham perseroan berimplikasi pada bersaran deviden, maka pembagian keuntungan kepada masingmasing pemilik saham sebagai modal perusahaan berbanding lurus dengan prosentase kepemilikan sahamnya. Hal ini secara tegas di tentukan dalam Pasal 32 Peraturan Daerah Propinsi NTB Nomor 4 Tahun 2010 tentang PT. Daerah Maju Bersaing yaitu :

"Pembagian laba bersih setelah dipotong pajak dan disahkan oleh RUPS, ditetapkan sebagai berikut, dividen untuk pemegang saham sebesar 90 persen, cadangan umum sebesar dua persen, cadangan tujuan 1,5 persen, dana kesejahteraan lima persen, dan jasa produksi 1,5 persen"

Dengan demikian secara yuridis normatif menunjukkan bahwa saham sebesar 25\% milik PT. DMB yang ditetapkan sebagai penyertaan modal pada PT. Multi Daerah Bersaiang merupakan harta kekayaan PT. DMB sebagai salah satu identitas dari Perseroan Terbatas (PT) yang akan dipergunakan untuk pengembangan usaha perseroan sesuai dengan maksud dan tujuan dibentuknya Perseroan. Terkait dengan PT. DMB berdasarkan ketentuan Pasal 5 Perda NTB Nomor 4 Tahun 2010 tentang Perseroan Terbatas bahwa maksud dibentuknya PT. DMB adalah untuk melakukan kerjasama dengan pihak ketiga dalam hal pembelian saham divestasi PT. Newmont Nusa Tenggara, mendayagunakan aset daerah dalam rangka menciptakan lapangan usaha, lapangan kerja dan peningkatan pendapatan asli daerah dengan tujuan untuk meningkatkan pertumbuhan perekonomian daerah dalam rangka memajukan kesejahtraan umum berdasarkan prinsip ekonomi perusahaan dan sesuai kelayakan usaha.

Dengan demikian nilai investasi hasil penjualan 25\% saham PT. DMB yang diambil alih (Penjualan) oleh PT.Multi Capital senilai Rp. 500.000.000.000 (lima ratus miliar) adalah kekayaan Perseroan yang akan dipergunakan untuk pengembangan usaha perseroan dalam upaya mencapai maksud dan tujuan dibentuknya perseroan yang akan ditetapkan dalam RUPS. Sedangkan nilai deviden dari kepemilikan saham sebesar 25\% Pada PT. Daerah Maju Bersaing selama 20112016 adalah sebesar Rp. 200.000.000.000 (dua ratus miliar) akan didistribusikan kepada masing-masing daerah sesuai dengan prosentase kepemilikan sahamnya pada PT. Daerah Maju Bersaing.

Sementara itu Berdasarkan ketentuan BAB VI tentang Bidang Usaha Pasal 6 PERDA Nomor 10 Tanun 2010 tentang PT.DMB menentukan bahwa tujuan pendirian PT.DMB selain menjalin kerjasama dengan PT. Multi 
Capital dalam pembelian saham divestasi PT. Newmont Nusa Tenggara juga adalah bidang usaha yang umumnya dilakukan oleh perusahaan komersial dan kegiatan lain sepanjang tidak bertentangan dengan peraturan perundang-undangan (sebagaimana dituangkan dalam Anggaran Dasar Perseroan terbatas beserta perbahannya).

Didalam Anggaran Dasar Pendirian Perseroan Terbatas Daerah Maju Bersaing khususnya pada Pasal 2 menyebutkan mahwa maksud dan tujuan perseroan adalah menyelenggarakan usaha dalam bidang :
a. Pertambangan
b. Pembangunan
c. Perdagangan
d. Perindustrian
e. Jasa. .

Oleh karena itu dengan terjualnya saham PT. DMB pada PT. MDB tidak secara otomatis menyebabkan Perusahaan menjadi bubar, karena secara yuridis normative, perusahaan masih dapat menjalankan bidang usaha lain selain bidang Pertambangan atau melakukan penyesuaian terhadap PP 54 Tahun 2017 tentang Badan Usaha Milik Daerah. Sebab terhadap Badan Usaha Milik Daerah yang dimiliki oleh lebih dari 1 Daerah khususnya yang berbentuk Perseroan Daerah maka wajib ada pemegang saham mayoritas $(>51 \%)$. PT. DMB dimiliki oleh tiga Daerah yaitu Propinsi 40\%, KSB 40\% dan KS 20\%).

Legalitas Pembubaran BUMD yang Berbadan Hukum PT. (PT. DMB). Secara historis, istilah BUMD pertama kali diatur dalam Peraturan Menteri Dalam Negeri Nomor 3 Tahun 1998 Tentang Badan Hukum Badan Usaha Milik Daerah.

Berdasarkan Ketentuan Pasal 2 Permendagri Nomor 3 Tahun 1998 tentang Badan Hukum Badan Usaha Milik Daerah menentukan bahwa Bentuk Badan Hukum Badan Usaha Milik Daerah terdiri dari

a. Perusahaan Daerah

b. Perseroan Daerah

Kemudian dalam Pasal 3 menentukan bahwa terhadap Badan Hukum Perusahaan Daerah tunduk pada Undang-undang Nomor
5 Tahun 1962 tentang Perusahan Daerah dan yang berbadan hukum Perseroan daerah tunduk pada Undang-undang Nomor 40 Tahun 2007 tentang Perseroan Terbatas.

Oleh karena itu baik terhadap proses pendirian maupun pembubaran suatu Badan Usaha Milik Darah menyesuaikan dengan bentuk badan hukum dari Badan Usaha Milik Daerah tersebut.

Dengan demikian Pendirian maupun pembubaran PT. DMB mengacu pada Undang-undang Nomor 40 Tahun 2007 tentang Perseroan Terbatas.

Bedasarkan ketentuan Pasal 34 Perda Nomor 4 Tahun 2010 tentang PT. DMB menentukan bahwa :

(1)Penggabungan, pemisahan, pengambilalihan dan pembubaran ditetapkan oleh RUPS/RUPS-LB setelah mendapatpersetujuanDPRDdanditetapkan dengan Peraturan Daerah.

(2)Perseroan dapat dibubarkan berdasarkan ; a. keputuasan RUPS/RUPS-LB dan /atau b. Penetapan Pengadilan.

(3)Tata Cara Penggabungan, pemisahan, pengambilalihan dan pembubaran Perseroan Terbatas sebagaimana pada ayat (1), dituangkan dalam anggaran dasar.

Jika merujuk pada Ayat (1), maka pembubaran suatu Perseroan Terbatas secara perosedural terlebih dahulu mendapatkan persetujuan DPRD dan ditetapkan dengan Peraturan Daerah (PERDA).

Ketentuan tersebut tentu bertentangan dengan Undang-undang Perseroan Terbatas sebagai payung hukum dalam pendirian maupun pembubaran suatu badan usaha milik daerah yang berbentuk Perseroan Terbatas (diatur dalam Pasal 142 s/d 146 UUPT). Disamping itu implementasi dari Pasal 2 ayat (1) Perda Nomor 4 tahun 2010 Tentang PT. DMB secara politik akan sulit untuk dilaksankan, karena PT. DMB dimiliki oleh tiga Daerah (Propinsi, Kabupaten Sumbawa dan Kabupaten Sumbawa Barat), sehingga yang menjadi persoalan adalah PERDA dari Pemerintah Daerah mana yang dimaksud (NTB, KSB, atau KS) karena dari sisi 
komposisi kepemilikan sahamnya belum ada yang mayoritas (40\%: 40\%:20\%). Sebab berdasarkan Undang-undangan Perseroan Terbatas (UU Nomor 40 Tahun 2007) bahwa kekuasaan tertinggi dalam Perseroan Terbatas adalah Rapat Umum Pemegang Saham (RUPS). Oleh karena itu dengan mengharuskan mendapatkan persetujuan Dewan sebelum dilakukannya RUPS , maka ketentuan ini bertentangan dengan asas lex superior drogat legi inferiori. Secara sosiologis, ada beberapa kelemahan dari ketentuan pasal 34 Perda Nomor 4 tahun 2010 tentang PT. Daerah Maju Bersaing yaitu :

1. Jika persetujuan DPRD menjadi dasar pelaksanaan RUPS Pembubaran PT. DMB, DPRD pemerintah Daerah mana dimaksud (mengingat PT. DMB dimiliki oleh tiga Pemerintah Daerah yaitu Pemda NTB, KS dan KSB).

2. Oleh karena yang disyaratkan adalah Persetujuan, maka pihak mana yang memiliki kewenangan untuk mengajukan permohonan (Prop. NTB, KS atau KSB).

3. Dengan ditetapkannya Persetujuan dan Peraturan Daerah sebagai syarat RUPS pembubaran PT. DMB, maka seolah-olah yang menyebabkan bubarnya PT. DMB adalah Peraturan Daerah. Sementara berdasarkan UUPT, lahir dan berakhirnya badanhukumPerseroanterbatasmerupakan kewenangan Kementerian Hukum dan Hak Asasi Manusia.

Pencantuman ketentuan Pasal 2 ayat (1) Perda Nomor 4 Tahun 2010 Tentang PT.DMB sepertinya terkontaminasi oleh proses pembubaran Perusahaan Daerah dalam Undang-undang Nomor 5 Tahun 1962 tentang Perusahan Daerah yaitu pada Pasal 29 menentukan : “Pembubaran Perusahaan Daerah dan penunjukan likuiditornya ditetapkan dengan Peraturan Daerah dari daerah yang menidirikan Perusahaan daerah dan yang berlaku setelah mendapat pengesahan instansi atasannya."

Ketentuan tersebut tentu lebih mudah untuk diiplementasikan, karena secara filosofi Perusahaan Daerah dimaksudkan bergerak dalam bidang pelayanan dan yang menguasai hajat hidup orang banyak dan dimiliki oleh satu Pemerintah Daerah, sehingga peran Dewan menjadi sangat penting dalam mengendalikan Perusahaan Daerah. Sedangkan Perseroan Terbatas lebih ditujukan pada mengejar keuntungan (profit oriented).

Diterbitkannya Undang-undang Republik Indonesia Nomor 23 Tahun 2014 Tentang Pemerintahan Daerah telah mencabut Undang-Undang Nomor 5 Tahun 1962 tentang Perusahaan Daerah, yang membuat kekosongan hukum terkait pengaturan mengenai Badan Usaha Milik Daerah (BUMD) yang komprehensif. Dengan kebutuhan tersebut maka disusunlah Peraturan Pemerintah Republik Indonesia Nomor 54 Tahun 2017 Tentang Badan Usaha Milik Daerah (selanjutnya disebut sebagai PP No. 54 Tahun 2017). Beberapa hal yang mendorong perlu adanya dasar hukum pengelolaan Badan Usaha Milik Daerah (selanjutnya disebut sebagai BUMD) antara lain, BUMD dianggap masih belum memiliki etos kerja, terlalu birokratis, inefisien, kurang memiliki orientasi pasar, tidak memiliki reputasi yang baik, profesionalisme yang rendah, masih banyaknya Pemerintah Daerah yang melakukan intervensi berlebihan terhadap BUMD, serta ketidakjelasan antara menghasilkan profit dan di sisi lain dituntut untuk memiliki fungsi sosial terhadap masyarakat dapat menyebabkan BUMD tidak fokus terhadap misi utamanya. Melihat dari hal-hal tersebut perlunya dikaji lebih lanjut mengenai organ kepengurusan dari BUMD sendiri.

BUMD terbagi menjadi 2 (dua), yaitu Perusahaan Umum Daerah (PERUMDA) dan Perusahaan Perseroan Daerah (PERSERODA). PERUMDA adalah BUMD yang seluruh modalnya dimiliki satu daerah dan tidak terbagi atas saham. Peseroda adalah BUMD yang berbentuk Perseroan Tebatas dengan modal yang terbagi atas saham yang seluruhnya atau paling sedikit 51\% (lima puluh satu persen) sahamnya dimiliki oleh 
1 (satu) daerah. Hal ini membuat perbedaan kedudukan Kepala Daerah selaku mewakili Pemerintah Daerah dalam Kepemilikan Kekayaan Daerah yang dipisahkan. Apabila dalam PERUMDA, Kepala Daerah berkedudukan sebagai pemilik modal (selanjutnya disebut KPM). Sedangkan apabila dalam PERSERODA, Kepala Daerah berkedudukan sebagai pemegang saham. Selain itu, berkaitan dengan organ kepengurusan BUMD sehari-hari, dalam BUMD berbentuk PERUMDA, berdasarkan Pasal 29 ayat (2) PP No. 54 Tahun 2017, organ BUMD terdiri atas KPM, Dewan Pengawas dan Direksi. Sementara berdasarkan Pasal 29 ayat (3) PP No. 54 Tahun 2017, organ BUMD berbentuk PERSERODA terdiri atas Rapat Umum Pemegang Saham, Komisaris dan Direksi.

Sebagaimana dijelaskan dalam Pasal 29 ayat (2) PP No. 54 Tahun 2017, organ PERUMDA terdiri dari KPM (yang setara dengan RUPS dalam PERSERODA), Dewan Pengawas (yang setara dengan Komisaris untuk PERSERODA) dan Direksi. Organ tertinggi dalam BUMD berbentuk PERUMDA adalah KPM untuk PERUMDA. Sementara organ tertinggi dalam BUMD berbentuk PERSERODA adalah RUPS. Ketentuan mengenai organ tertinggi ini dijelaskan dalam ketentuan Pasal 1 angka 14 PP No. 54 Tahun 2017 yang mengatur bahwa Kepala Daerah berkewenangan mewakili PERUMDA dalam hal kepemilikan kekayaan umum daerah yang dipisahkan pada PERUMDA. Dengan kata lain, Kepala Daerah berkedudukan sebagai pemilik modal dalam PERUMDA sebagaimana dinyatakan dalam Pasal 3 ayat (1) PP No. 54 Tahun 2017. Kewenangan Kepala Daerah sebagai pemilik modal tersebut meliputi kewenangan dalam pengambilan keputusan untuk PERUMDA. Pasal 1 angka 15 PP No 54 Tahun 2017 menjelaskan bahwa RUPS adalah organ pemegang kekuasaan tertinggi dalam PERSERODA. RUPS berwenang atas segala hal yang tidak diberikan kepada Direksi atau Komisaris. Dalam hal ini Kepala Daerah merupakan wakil Daerah selaku pemegang saham perusahaan perseroan Daerah di RUPS atau dapat juga memberikan kuasa berupa hak substitusi kepada pejabat Pemerintah Daerah.

Organ kedua dalam PERUMDA adalah Dewan Pengawas atau setara dengan Komisaris untuk PERSERODA). Pasal 37 PP No 54 Tahun 2017 menjelaskan bahwa Dewan Pengawas dalam PERUMDA ditunjuk oleh KPM, sedangkan Komisaris dalam PERSERODA ditunjuk oleh RUPS. Dewan Pengawas atau Komisaris dapat terdiri dari unsur independen maupun unsur lainnya seperti Pejabat Pemerintah Pusat dan Pejabat Pemerintah Daerah yang tidak bertugas melakukan pelayanan publik selama sesuai dengan ketentuan peraturan perundangundangan. Tugas serta kewenangan Dewan Pengawas atau Komisaris diatur dalam Pasal 43 PP No 54 Tahun 2017. Dewan Pengawas dan Komisaris bertugas melakukan pengawasan terhadap jalannya BUMD masing-masing serta memberikan masukan kepada Direksi dalam menjalankan tugasnya. Selain melakukan pengawasan, Dewan Pengawas dalam PERUMDA juga wajib melaporkan hasil pengawasan mereka kepada KPM. Senada dengan Dewan Pengawas, Komisaris dalam PERSERODA juga wajib melaporkan hasil pengawasan mereka kepada RUPS. Dewan Pengawas atau Komisaris tidak diperbolehkan untuk memangku jabatan rangkap dalam menjalankan tugasnya sebagaimana disebutkan dalam ketentuan dalam Pasal 49 PP No 54 Tahun 2017 Tentang Badan Usaha Milik Daerah.

Organ ketiga dalam BUMD adalah Direksi. Ketentuan mengenai Direksi BUMD diatur dalam Pasal 55 sampai dengan Pasal 73 PP No 54 Tahun 2017. Dalam PERUMDA, Direksi diangkat oleh KPM sementara Direksi dalam PERSERODA diangkat oleh RUPS, dengan tugas serta wewenang yang diatur dalam Anggaran Dasar BUMD. Sejalan dengan ketentuan Dewan Pengawas atau Komisaris, Direksi dilarang memangku jabatan rangkap sebagai anggota Direksi Perusahaan lain, jabatan yang dapat menimbulkan konflik 
kepentingan, maupun yang dilarang oleh peraturan perundang-undangan.

Atas dasar berbagai argumentasi tersebut diatas, maka secara yuridis normative Peraturan Pemerintah Nomor 54 Tahun 2017 Tentang Badan Usaha Milik Daerah, belum dapat diberlakukan terhadap pembubaran PT. Daerah Maju Bersaing dengan alasan :

1. Bertentangandenganasas Non RetroAktive ( Tidak dapat berlaku surut)

2. PT.DaerahMajuBersaingmerupakanBadan Usaha yang dirikan oleh Tiga Pemerintah Daerah yaitu Pemprop NTB (40\%), KSB (40\%) dan Kabupaten Sumbawa (20\%), sehingga belum memenuhi unsur BUMD yang berbentuk Perseroan Daerah yaitu harus ada yang memiliki saham mayoritas $(50+1)$. Sehingga status PT. DMB murni Perseroan Terbatas yang tunduk pada UU Nomor 40 tahun 2007 tentang Perseroan Terbatas.

Oleh karena itu ketentuan pasal 34 tersebut harus ditafsirkan secara sistimatis dan mengacu pada asas lex posterior derogate legi prior secara procedural pembubaran PT. DMB mengikuti tatacara yang diatur dalam Undang-undang Nomor 40 Tahun 2007 tentang Perseroan Terbatas yaitu Rapat Umum Pemegang Saham tentang pembubaran, pengumuman dalam surat kabar, RUPS pembagian Asset dan keuangan, pengumuman dalam surat kabar, penghapusan dalam lembaran Negara, Pencabutan Perda tentang PT. DMB (sebagaimana halnya ketika didirikan). Artinya setelah seluruh peroses yang diharuskan oleh Peraturan Perundang-undangan dilaksanakan langkah berikutnya diikuti dengan Persetujuan Dewan dan Peraturan Daerah (Lex Superior drogat legi inferiori).

\section{KESIMPULAN}

1. Penjualan saham PT.DMB pada Perusahaan PT.MDB tidak secara otomatis menyebabkan PT.DMB bubar.

2. Pembubaran PT. DMB secara yuridis normative harus tetap mengacu pada
Undang-undang Nomor 40 Tahun 2007 Tentang Perseroan Terbatas.

3. Pembubaran Perseroan Terbatas sebagaimana diatur dalam Perda Nomor 4 Tahun 2010 Tentang PT.DMB bertentangan asas Lex Superior drogat legi inferiori).

4. PersetujuanDewandanPenetapanPeraturan Daerah Pembubaran PT. DMB dilakukan setelah proses pembubaran PT dilakukan berdasarkan UU PT (sebagaimana halnya ketika pendirian PT. DMB yaitu Perda Tentang PT. DMB ditetapkan setelah akta pendiriannya Mendapat Pengesahan Kementrian Hukum dan HAM).

\section{DAFTAR PUSTAKA}

\section{Buku}

Indonesia Corruption Watch www. antikorupsi.org Jakarta, 10 Juni 2016 yang diakses pada Tanggal 9 Agustus 2018

Erman Radjagukguk dalam tulisannya "Joint-Venture Policy Relationship Between Majority And Minority Shareholers". Tanpa tahun

\section{Peraturan Perundang-undangan}

Undang-undang Nomor 23 Tahun 2014 tentang Pemerintahan Daerah

Undang-undang Nomor 40 Tahun 2007 tentang Perseroan Terbatas

Peraturan Pemerintah Nomor 54 Tahun 2017 tentang Badan Usaha Milik Daerah

Peraturan Daerah Nomor 4 Tahun 2010 tentang PT. Daerah Maju Bersaing 